\title{
Substrate Preferences of Ruderal Plants in Colonizing Stone Monuments of the Pasargadae World Heritage Site, Iran
}

\author{
Zohreh Hosseini *(D), Giulio Zangari, Marta Carboni (D) and Giulia Caneva (D) \\ Department of Science, University of Roma Tre, 00146 Rome, Italy; giulio.zangari@uniroma3.it (G.Z.); \\ marta.carboni@uniroma3.it (M.C.); giulia.caneva@uniroma3.it (G.C.) \\ * Correspondence: Seyedhzohreh.hosseini@uniroma3.it; Tel.: +39-06-5733-6374
}

Citation: Hosseini, Z.; Zangari, G.; Carboni, M.; Caneva, G. Substrate Preferences of Ruderal Plants in Colonizing Stone Monuments of the Pasargadae World Heritage Site, Iran. Sustainability 2021, 13, 9381. https:// doi.org/10.3390/su13169381

Academic Editor: C. Ronald Carroll

Received: 1 July 2021

Accepted: 18 August 2021

Published: 20 August 2021

Publisher's Note: MDPI stays neutral with regard to jurisdictional claims in published maps and institutional affiliations.

Copyright: (c) 2021 by the authors. Licensee MDPI, Basel, Switzerland. This article is an open access article distributed under the terms and conditions of the Creative Commons Attribution (CC BY) license (https:// creativecommons.org/licenses/by/ $4.0 /)$.

\begin{abstract}
Plant colonization on archaeological structures is limited by the substrate conditions of stone surfaces. Despite its relevance for ecological studies and the management plans of archaeological sites, the knowledge on monuments substrate (e.g., stones, microhabitats, microsites), which could be suitable sites for plant establishment, is an underestimated topic. Here, we aim to identify the substrate preference of plants in colonizing stone surfaces as a first step in evaluating the biodeterioration risk. We selected the Pasargadae World Heritage Site (WHS) for its variety of different conditions, and we assessed the substrate preference of 142 ruderal plants occurring on nine monuments, two types of stones, and eight microsites. Our data indicated that stone typology and microsite conditions affected species composition, diversity, and richness. The porosity of the different limestone and the progressive weathering phenomena resulted as relevant factors in plant colonization. Significantly, microsites as a junction of two stone blocks (M1a) and big fractures covered by soil (M3) hosted the most favorable conditions, which needed periodic monitoring during the maintenance activities of the site. Evaluating the substrate preference of ruderal plants can contribute to the identification of the high-risk areas for plant colonization, which need to be considered in the management plans of archaeological sites.
\end{abstract}

Keywords: archaeological sites; biodeterioration; cultural heritage conservation; stone colonization; higher plants; plant management; plant ecology; plant settlements; ruderal vegetation

\section{Introduction}

In archaeological areas, historical structures and ruins are common habitats for plant colonization [1-6]. As with rocky surfaces, walls and building structures usually represent complex habitats for plant establishment [6-8]. In general, plant colonization is highly restricted by the ecological adaptability of species, the strategy and efficiency of their reproduction [9]. In pioneer conditions, small herbaceous annual plants are the most common species, then perennials herbaceous species prevail, followed by shrubs and trees [10].

Many studies evaluate which ruderal plants can colonize monuments in archaeological sites by considering their ecological features, especially those that can pose a hazard to monuments [11-15]. The highest number of investigations has been referred to archaeological sites within the Mediterranean basin [2,5,12,16-22], while limited research describes the ruderal vegetation in arid and semi-arid bioclimates $[14,15,19,23,24]$ or the tropical conditions of Mesoamerica [25] and Asia [26-29]. Indeed, relevant restricted factors are the bioclimatic and microclimatic conditions, such as rainfall, humidity, and temperatures, which also vary in relation to exposure and inclination $[6,10,22,30]$. Arid and semi-arid bioclimates create xeric conditions due to the water deficiency and high temperatures, limiting the biological colonization [31-33]. However, these conditions can still favor the growth of different endolithic communities and give rise to various microbiological deterioration processes [34,35]. 
In addition to the above-mentioned environmental conditions [5], the chemical and physical characteristics of the substrate play a significant role in restricting the biological colonization of ruins [22]. In particular, the bioreceptivity of stone, which is related to the porosity of the substrate and past weathering phenomena, has a significant influence [36-40]. The maintenance also affects the colonization rate on structures and negligence increases the bioreceptivity of building materials to plant colonization [4,22,39,41,42]. In fact, natural weathering or anthropic factors tend to increase stone porosity, grain disintegration, formation of cracks and fissures, fostering the settlement of microorganisms, as well as higher plant establishments [4,43]. The dust and organic matter trapped between the substrate's fissures, cracks, and cavities provide a fertile environment for plant colonization, resulting in a more diverse population of plants with a more remarkable ability to adapt $[8,44]$.

In general, although the importance of the habitat on historical structures has been underlined by various authors $[4,24,45]$, no significant attention has been given to the role of the substrate conditions in determining the plant colonization on structures. The places that provide suitable conditions for plant settlement on a man-made structure at a micro-scale are known as microsites (MS), i.e., sites analyzed at a detailed scale [24,45]. The knowledge of factors determining the pattern of species composition in the different microsites has an ecological interest, and it seems essential in assessing the potential hazard of plants to historic structures [24]. Furthermore, the knowledge of wall species' ecological features and their natural habitat can help to better manage the plant communities growing on archaeological remains.

The various conditions of the Pasargadae World Heritage Site (WHS) made it an excellent representative archeological site. In the northwest of Fars province in Southern Iran, the Pasargadae WHS is located in the Murghab plain (1800 m above sea level), one of the vaster alluvial sedimentary intermountain basins within the Zagros Mountain chain [46], which is an important habitat of the Zagros ecological zone [47]. Pasargadae was the capital of an empire, which dominated the ancient Near East for more than two centuries [48]. This site dates back to the Achaemenid Empire, founded by Cyrus the Great in 550-530 BCE [49,50], and it illustrates the art and architecture of the early Achaemenid period [49,51]. This region was strategically favored as the capital of the empire due to the natural advantages such as a cluster of mountains, a favorable climate, available water resources, and easy access to the region's important centers within the Fars Province [49,51]. The well-watered basin and vast surface of arable land were considered as an important factor in the choice of the site [52], and currently provide a favorable area for agricultural development [53]. In addition to four permanent villages and agricultural lands, this area hosts annual nomadic encampments, and it represents a site for pastoralism [54].

The bioclimate of the Pasargadae region belongs to the Mediterranean Xeric Continental climate that covers a relatively large part of the Zagros Mountains in the southern section and is characterized by hot, dry summers and relatively cold winters [55]. The average annual precipitation is $337 \mathrm{~mm}$, and all the rain falls from December to May, while there is a completely dry season from June to September. The average annual temperature is $12.4^{\circ} \mathrm{C}$, although there is a wide annual excursion considering the absolute minimum of $-10.6{ }^{\circ} \mathrm{C}$ in February and the absolute maximum of $44.4{ }^{\circ} \mathrm{C}$ in July (data from 1996 to 2009 , in [46]). Additionally, the mean relative humidity is $39-41 \%$, with wide excursions (http:/ / www.irimo.ir, accessed on 1 September 2014). These dry conditions can be locally limited when the phreatic layers become more superficial or in sites where the rainfall is funneled in ephemeral flows.

In a previous paper, we evaluated the potential hazards of MS colonization on stone monuments of the Pasargadae WHS as a tool for a general risk assessment of biodeterioration in the case of no visible damage [24]. In such a paper, we described the various MSs occurring in Pasargadae, noting their frequent recurrence and hazard for monuments. Among them, the most frequent MSs for plant colonization were joints and big fractures of stone blocks (M1a) and soil-covered surfaces (M3). These MSs also resulted as potentially 
dangerous for the monument integrity due to the easy root expansions and the lower environmental stress [24]. However, the establishment of their suitability for plant colonization indicated the need for a deeper statistical investigation on the ecological features of MS and their correlations with ruderal plants. The main aim of this study is to analyze in-depth the local conditions that promote the colonization of the ruderal flora in the Pasargadae WHS, a high significant archaeological site in a poorly investigated geographical area. Then, we analyze the monuments, stone, and microsites as the main substrate elements, explaining their role in plant colonization.

\section{Materials and Methods}

2.1. Methodology for the Assessment of Substrate Preferences of Plants

\subsubsection{Dataset for Substrate Conditions}

In the archaeological area, monuments (Figure 1), with the related stone and MS representing significant indicators of the substrate conditions, considering that stone surfaces are often covered by a certain amount of soil (Figure 2).

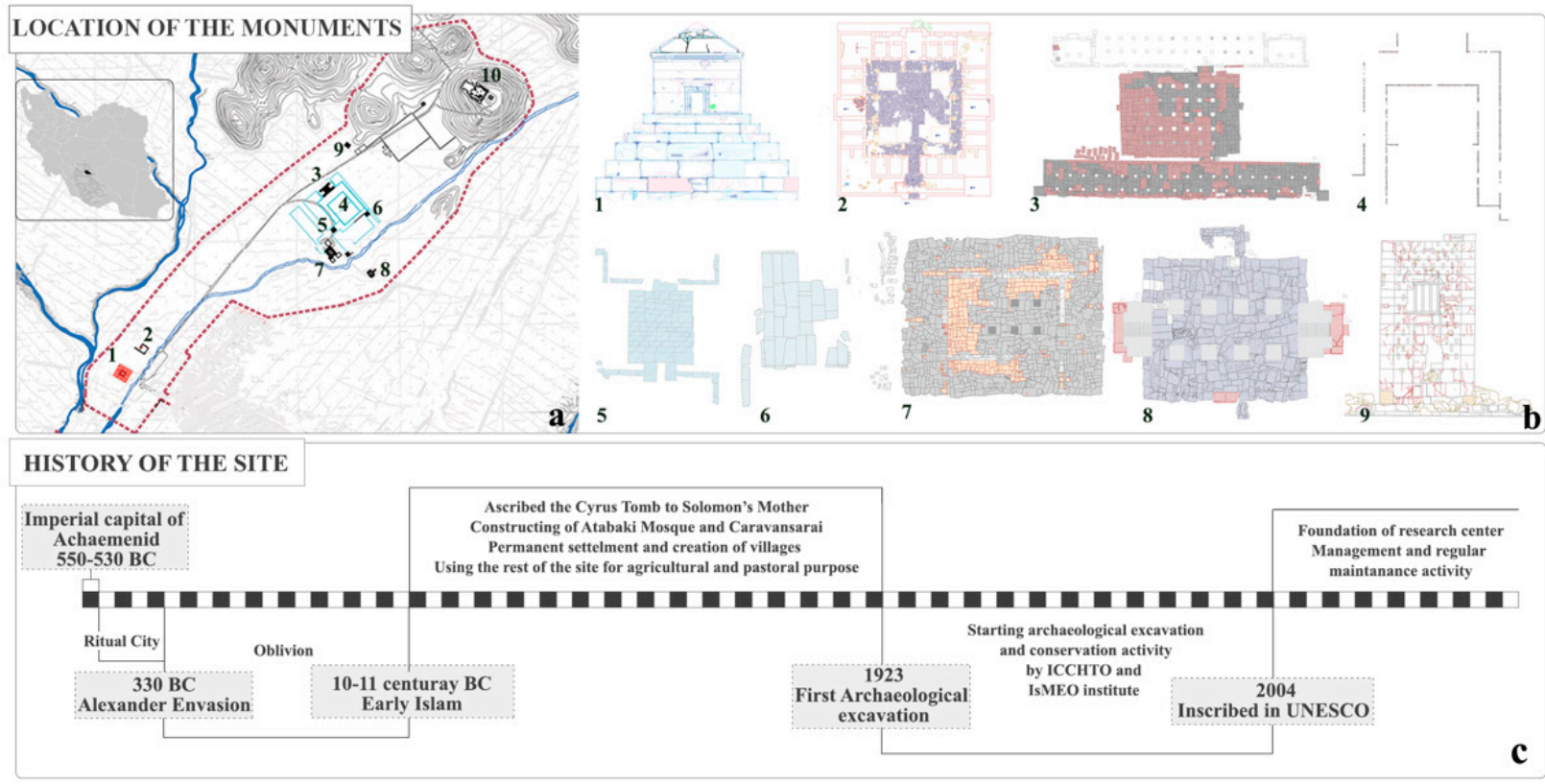

Figure 1. Study site: Pasargadae WHS: (a) The geographical location of the site in Iran and of the monuments within the site, (b) plans of the documented monuments, (1) Tomb of Cyrus the Great, (2) Caravanserai, (3) Private Palace, (4) Watercourses of the Royal Garden, (5) Pavilion B, (6) Pavilion A, (7) Audience Hall, (8) Gatehouse, (9) Stone Tower, and (10) the Fortified Terrace which was not included in our study (photo credits: Archive of Pasargadae research center). (c) Summary of the most relevant steps in the history of the site.

Monuments: The Pasargadae WHS consists of 10 monuments, including the Tomb of Cyrus the Great (CyT), Caravanserai (Ca), Private Palace (PP), Watercourses of Royal Garden (WaC) and its Pavilions (PaA and PaB), Audience Hall (PS), Gatehouse (PR), Stone Tower (ST), and an earthen fortified terrace (Tal-e Takht) (Figure 1). In this analysis, we considered the first nine monuments, since the fortified terrace was not accessible for the survey. The extension, stone materials, and management activities highly vary among the monuments (see Table S1 in Supplementary), as recorded from the annual reports in the archive of Pasargadae research center and during field surveys in 2019 and 2020. We considered each monument as an individual sampling area, even if several observations for each monument were carried out. 


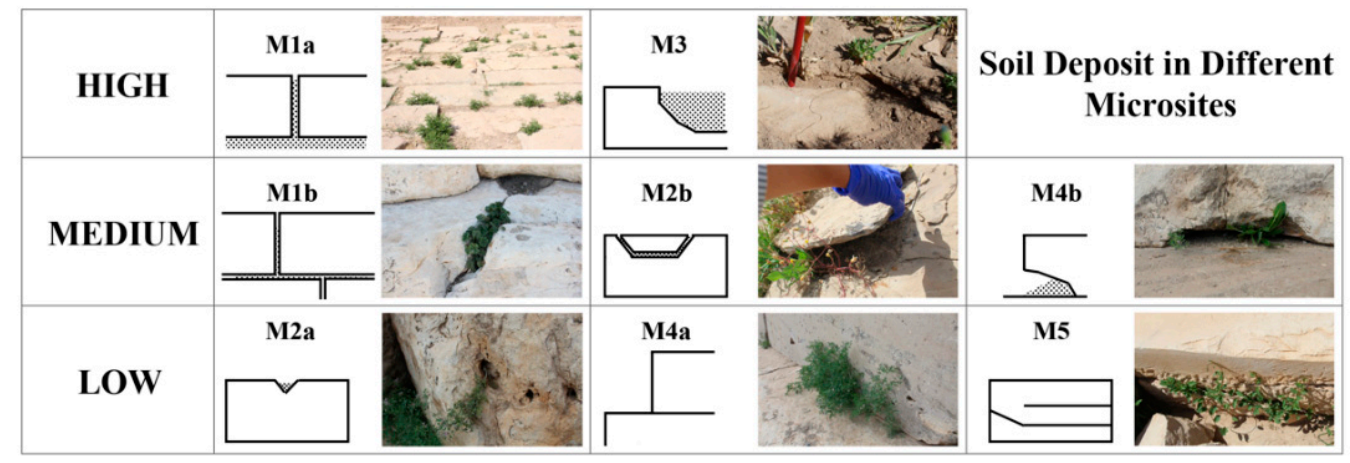

Figure 2. The rate of soil deposit in different microsites. (M1a) Joints and fractures between two stone blocks; (M3) big fractures covered by soil; (M1b) narrow joints between two stone blocks; (M2b) delamination and damaged parts of stone; (M4b) fractures and cavities at vertical/horizontal junctions; (M2a) cavities of homogenous surface; (M4a) narrow vertical/horizontal junctions; (M5) areas between sedimentary layers of stone blocks.

Stone typologies: Stones are the main construction material in the Pasargadae complex. Their classification is based on their practical attributes (i.e., strength, durability) and according to their physical appearance, we could distinguish three types of limestones, called Beige (BS), Green-Gray (GGS), and Dark Gray stones (DGS). Green-Gray stone is an argillaceous limestone, with cross cracks and micro-fractures and small quartz and non-swelling clay minerals. Its different phases, such as quartz and clay minerals, and calcite, as well as $25-30 \%$ of interparticle porosity, cause an inherent susceptibility to weathering. This kind of stone was used for the foundation of buildings. Beige stone is a pure aspartic limestone, with compact homogenous texture and uniform composition of calcite and dolomite, and quarts as aggregates of insoluble residues. There is less porosity in calcite-dolomite stone (BS) and a lower quartz content (less than $5 \%$ in respect to GGS with 15-20\%), which makes them more compact in comparison with GGS and DGS [56-59]. This stone was used for bases, columns, the Cyrus the Great tomb, and the Stone Tower. In this analysis, we excluded DGS due to its use in inaccessible locations for plant colonization (base of columns and gates) and its use in well-maintained decorative parts. Therefore, we had a low recurrence of this substrate for plant colonization.

Microsites: We considered eight microsites for plant establishment on the monuments of Pasargadae, following their previous classification [24]: M1a-joints and fractures between two stone blocks; M1b-narrow joints between two stone blocks; M2a-cavities of homogenous surface; $\mathrm{M} 2 \mathrm{~b}$ - delamination and damaged parts of stone; M3 - big fractures covered by soil; M4a - narrow vertical/horizontal junctions; M4b-fractures and cavities at vertical/horizontal junctions; M5-areas between sedimentary layers of stone blocks (Figure 2). We excluded substrates formed on ruined stonework (I) and cavities in a vertical face of homogeneous material (D), due to their rare occurrence within the site. The following indicators distinguished the considered microsites: the possibility of root penetration in the substrate, root expansion, the presence of soil deposit, water availability, and protection from environmental stressors.

\subsubsection{Floristic Dataset}

We used the ruderal flora checklist of 142 plant species occurring in the study area [24] as the main floristic reference. In the present analysis, we also considered each species coverage. Vegetation data were recorded in the field through visual observations according to the Braun-Blanquet cover-abundance scale ( $+=$ sporadic species; $1=<5 \% ; 2=5-25 \%$; $3=25-50 \% ; 4=50-75 \% ; 5=>75 \%$ ) [60]. Then, we built three matrices, where the rows were the quali-quantitative data (plant presence and covers), and the columns were, respectively: (a) the nine analyzed monuments; (b) the two stone typology; (c) the eight described microsites (Table S2 in Supplementary Materials). We also grouped the collected plant species according to their life forms, i.e., their structural characteristics, which were observed 
during the field surveys. Their classification followed the Raunkiaer's [61] categories (Therophytes (T): annual herbs; Hemicryptophytes $(\mathrm{H})$ : perennial herbs; Geophytes $(\mathrm{G})$ : perennial herbs with underground storage organs; Chamaephytes $(\mathrm{Ch})$ : woody plants with buds at no more than $25 \mathrm{~cm}$ above the soil surface; Phanerophytes (P): trees and shrubs with buds over $25 \mathrm{~cm}$ above the soil surface).

\subsection{Statistical Evaluations}

We used the Past (Paleontological Statistics) software package for all the analyses (https: / / past.en.lo4d.com/windows, accessed on 3 June 2020), and we converted the plant coverage data from the Braun-Blanquet cover-abundance scale into ordinal transformations following the scale of van der Maarel [60].

\subsubsection{Classification and Ordination}

We used the Hierarchical Cluster Analysis (HCA), using the single-linkage method, which joins clusters based on the smallest distance between the two groups [62] to identify the plant composition patterns on the different monuments, as well as different MSs. For the ordination for the resulting data, we also used the Principal Component Analysis (PCA, based on single-linkage and Euclidean similarity distance). We evaluated the potential correlation of plant distribution with each MS, using non-metric multidimensional scaling NMDS ordination, using the Euclidean similarity index, and considering the coverage of species in the MSs.

In addition, we also calculated the deviation between the average cover values of species in the different monuments, stone typology, and MSs, to evaluate the differential preference of species to the ecological conditions of each variable.

\subsubsection{Distribution Models and Detrended Correspondence Analysis (DCA)}

We also used Species Abundance Distribution (SAD) models, which shed light on community characteristics $[63,64]$. We evaluated the species correlation with each MS based on their biological forms by a Detrended Correspondence Analysis (DCA) $[65,66]$. DCA rescales the axes while all species show a unimodal response curve with homogeneous variances along each gradient. This rescaling procedure tends to expand interpoint spacing between sites or species located at the ends of the axes [65,66]. Ellipses with 95\% of confidence were plotted to put more weight on the regions with the highest frequency. Additionally, we evaluated the adaptability of the plant species in the colonization of different MSs, by considering the most five abundant species in each MS and highlighting the species that showed a preferential MS. For SAD and DCA, we considered the average of species cover in different monuments, stones, and MSs.

\section{Results}

\subsection{Plant Colonization Similarity among the Monuments}

The analysis of the plant biodiversity in the different monuments showed a high variation in floristic richness among monuments and a significant difference in plant coverage. Watercourses and the Private Palace showed the highest floristic richness, and in particular, Watercourses resulted as the most favorable place for plant colonization, with the highest values of biodiversity (139 among 142 species), while only 22 species were observed in the Cyrus Tomb.

Although the results of the cluster analysis showed a certain similarity in the vegetation (i.e., also considering quantitative data of plant colonization) growing on most of the monuments, two main floristic groups were evident (first group: PP, PS, PR; second group: $\mathrm{PaB}, \mathrm{PaA}, \mathrm{ST}$ ). At the same time, more different species compositions (Figure 3a) were detectable in three monuments $(\mathrm{Ca}, \mathrm{WaC}$ and $\mathrm{CyT})$. The species with the most differential preference for each monument are shown in Table 1. 
The results of the PCA analysis (Figure 3b) showed a clear gradient following the first axis, which explains $37.8 \%$ of variability, putting $\mathrm{CyT}$ and $\mathrm{WaC}$ at the extreme conditions of such a trend. Following the second axis (17\% of variability), WaC and Ca were in opposite conditions, whereas most of the other monuments were located very close. In particular, Ca showed the highest differences with respect to all the others.
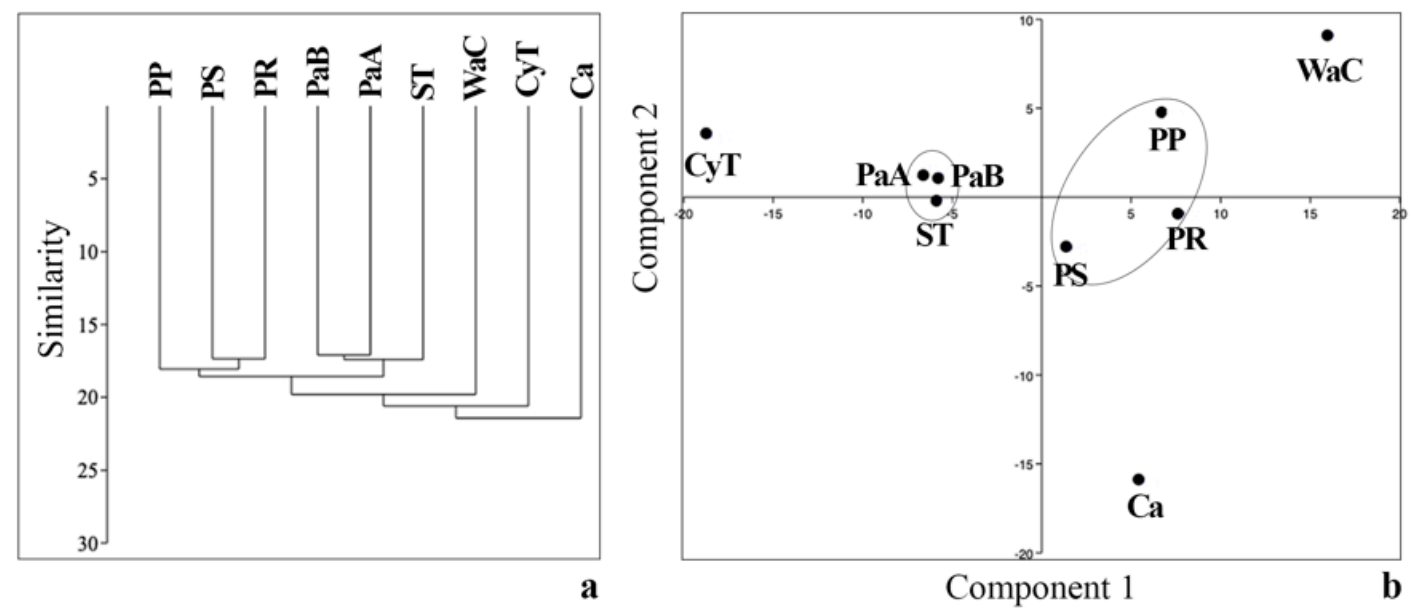

Figure 3. Classification and ordination of vegetation data in Pasargadae: (a) HCA of the similarity rate in plant species composition among the different monuments. (b) PCA analysis of the plant composition in the monuments. CyT-Cyrus Tomb; Ca-Caravanserai; PP_Private Palace; WaC-Watercourses; PaA-Pavilion A; PaB-Pavilion B; PS-Audience Hall; PR-Gatehouse, ST-Stone Tower.

Table 1. The most recurring (top ten) species in the groups of monuments of Pasargadae, detected by the HCA and PCA analyses.

\begin{tabular}{|c|c|c|c|c|c|}
\hline & $\mathrm{Ca}$ & СуТ & $\mathrm{WaC}$ & $\mathrm{PaB}, \mathrm{PaA}, \mathrm{ST}$ & PP, PS, PR \\
\hline 1 & Adonis aestivalis & Ficus johannis & Alhagi maurorum & Glycyrrhiza glabra* & Centaurea bruguierana \\
\hline 2 & Sisymbrium septulatum & Cirsium sp. & Alhagi pseudalhagi & Galium tricornutum & Cyanus depressus \\
\hline 3 & Cynodon dactylon * & Sanguisorba minor & Camelina hispida & Alopecurus arundinaceus & Senecio glaucus \\
\hline 4 & Falcaria vulgaris & Allium atroviolaceum & Glycyrrhiza glabra * & Bromus tomentellus & Lactuca scarioloides \\
\hline 5 & Melica persica * & Moltkia longiflora & Lappula sp. & Cynodon dactylon * & Poa bulbosa \\
\hline 6 & Descurainia sophia & Solanum nigrum & Sonchus oleraceus & Alyssum heterotrichum & Euphorbia dracunculoides \\
\hline 7 & Hordeum distichon & Malva neglecta & Marrubium cordatum & Euphorbia sororia & Lepidium draba \\
\hline 8 & Galium ceratopodum & Koelpinia linearis & Marrubium cuneatum & Melica persica * & Tragopogon collinus \\
\hline 9 & Lactuca orientalis * & Roemeria hybrida & Scorzonera tunicata & Silene sisianica & Boissiera squarrosa \\
\hline 10 & Galium setaceum & Roemeria refracta & Lactuca orientalis * & Medicago monantha & Taeniatherum caputmedusae \\
\hline
\end{tabular}

\subsection{Stone Preference for Plant Colonization}

Evaluating the colonization of plants on the two stones, both Beige stone and GreenGray stone resulted in a high degree of colonization by plants. Green-Gray stone had the most species richness since, among 142 species, 139 species could colonize it. Despite the colonization of 119 species on Beige stone, these species were less abundant than those on Green-Gray stone (Table 2). Looking at the PCA related to species composition of the two stones in the different monuments (Figure 4a), the results were similar with respect to the general analysis of floristic patterns in monuments. The first axis explains $48 \%$ of the variability and the second one $13 \%$ of the variability.

The Species Abundance Distribution (SAD), which is represented by rank-abundance plots, is shown in Figure $4 b$,c, where all the species in a sample were ranked from the most abundant to the least abundant ones. Each species had a rank plotted on the $x$-axis, and an abundance plotted on the $y$-axis. This graph shows that only a few species had high cover values, whereas many species had a low abundance. On Beige stone, a high number of species (approximately 60) were observed with a low abundance (1 value, based on the Van der Maarel scale). Conversely, on Green-Gray stone, the number of species with a low 
abundance was notably lower and species with a higher abundance were noticeably more numerous, which proved its suitability for plant colonization. The $p$-value of $7.76 \times 10^{-10}$ shows the significance of this analysis $(p<0.05,[67])$.
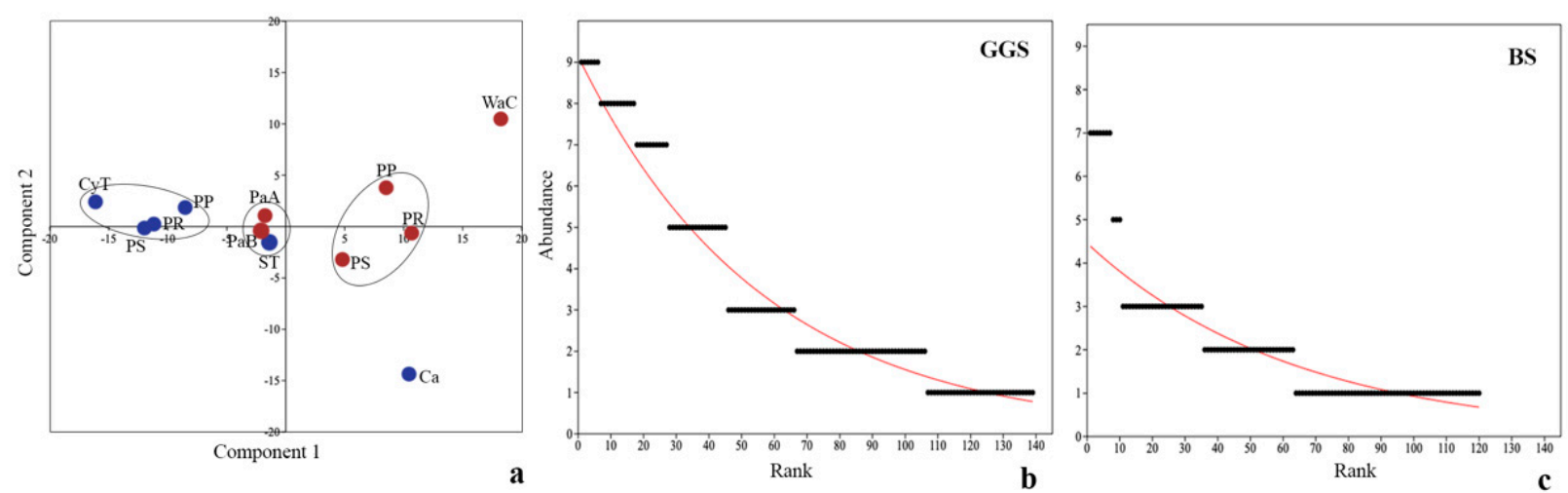

Figure 4. Vegetation preference based on stone typology in Pasargadae, through ordination and species abundance distribution: (a) PCA of plant colonization on different stones (blue points-Beige stone; red points-Green-Gray stone; CyT_Cyrus Tomb; Ca_Caravanserai; PP—Private Palace; WaC—Watercourses; PaA-Pavilion A; PaB—Pavilion B; PSAudience Hall; PR-Gatehouse; ST—Stone Tower). (b) Average abundance of species on Green-Gray stone. (c) Average abundance distribution of species on Beige stone. In both graphs, numbers on the $y$-axis express the average abundance based on the Van der Maarel scale and numbers in $x$-axes (ranks) indicate the number of occurring species for each cover value. The length of the lines displays the number of species that have such abundance value.

Table 2. Species with a clear preference for a typology of stones (BS, GGS), following decreasing values: (a) species with a preference for GGS and (b) species with a preference for BS $\left(^{*}\right)$.

(a)

\begin{tabular}{|c|c|c|c|c|c|c|c|}
\hline \multirow{2}{*}{ Species } & \multicolumn{3}{|c|}{ (Average Cover) } & \multirow{2}{*}{$\begin{array}{c}\text { Silene sisianica } \\
\text { Alhagi maurorum }\end{array}$} & \multirow{2}{*}{$\begin{array}{l}1.0 \\
0.7\end{array}$} & \multirow{2}{*}{$\begin{array}{l}2.8 \\
2.5\end{array}$} & \multirow{2}{*}{$\begin{array}{l}1.8 \\
1.8\end{array}$} \\
\hline & BS & GGS & dev & & & & \\
\hline Glycyrrhiza glabra & 0.2 & 4.3 & 4.2 & Sisymbrium septulatum & 1.3 & 3.0 & 1.7 \\
\hline Senecio glaucus & 1.8 & 5.0 & 3.2 & Boissiera squarrosa & 0.3 & 2.0 & 1.7 \\
\hline Falcaria vulgaris & 2.8 & 6.0 & 3.2 & Hordeum bulbosum & 3.7 & 5.3 & 1.7 \\
\hline Lactuca scarioloides & 1.3 & 4.3 & 3.0 & Lactuca orientalis & 1.0 & 2.7 & 1.7 \\
\hline Crepis sancta & 0.5 & 3.3 & 2.8 & Alopecurus arundinaceus & 0.5 & 2.2 & 1.7 \\
\hline Euphorbia dracunculoides & 0.7 & 3.3 & 2.7 & & & & \\
\hline Cyanus depressus & 1.0 & 3.7 & 2.7 & \multicolumn{4}{|c|}{ (b) } \\
\hline Podospermum grossheimii & 1.3 & 3.8 & 2.5 & \multirow{2}{*}{ Species } & \multicolumn{3}{|c|}{ (Average Cover) } \\
\hline Poa bulbosa & 2.2 & 4.5 & 2.3 & & BS & GGS & dev \\
\hline Medicago monantha & 1.5 & 3.8 & 2.3 & Adonis aestivalis & 0.8 & 0.0 & -0.8 \\
\hline Medicago persica & 1.5 & 3.8 & 2.3 & Peganum harmala & 0.5 & 0.0 & -0.5 \\
\hline Centaurea bruguierana & 1.0 & 3.3 & 2.3 & Zoegea leptaurea & 1.0 & 0.7 & -0.3 \\
\hline Lepidium draba & 1.7 & 4.0 & 2.3 & Papaver argemone & 0.8 & 0.5 & -0.3 \\
\hline Alhagi pseudalhagi & 0.7 & 2.8 & 2.2 & Scandix stellata & 0.3 & 0.2 & -0.2 \\
\hline Rostraria cristata & 0.0 & 2.2 & 2.2 & Euphorbia sororia & 0.2 & 0.0 & -0.2 \\
\hline Lactuca serriola & 2.0 & 4.0 & 2.0 & Geranium kotschyi & 0.2 & 0.0 & -0.2 \\
\hline Scorzonera cinerea & 2.0 & 4.0 & 2.0 & Ficus johannis & 0.2 & 0.0 & -0.2 \\
\hline Tragopogon graminifolius & 1.8 & 3.8 & 2.0 & Nonea longiflora & 1.0 & 0.8 & -0.2 \\
\hline
\end{tabular}

* The values indicate the average cover of the species growing on the two stones (Van der Maarel scale); devdeviation considers the differences among the most extreme values. 


\subsection{Vegetation Patterns in Microsites}

The NMDS ordination of plants growing at the MSs (Figure 5a) showed a clear separation for species composition and cover for M1a and M3, whereas the other MSs showed overlapping. When applying a cluster analysis for the MS similarities in vegetation patterns, four groups were detectable (Figure $5 b$ ) and the NMDS of MS groups showed a clearer separation (Figure 5c).
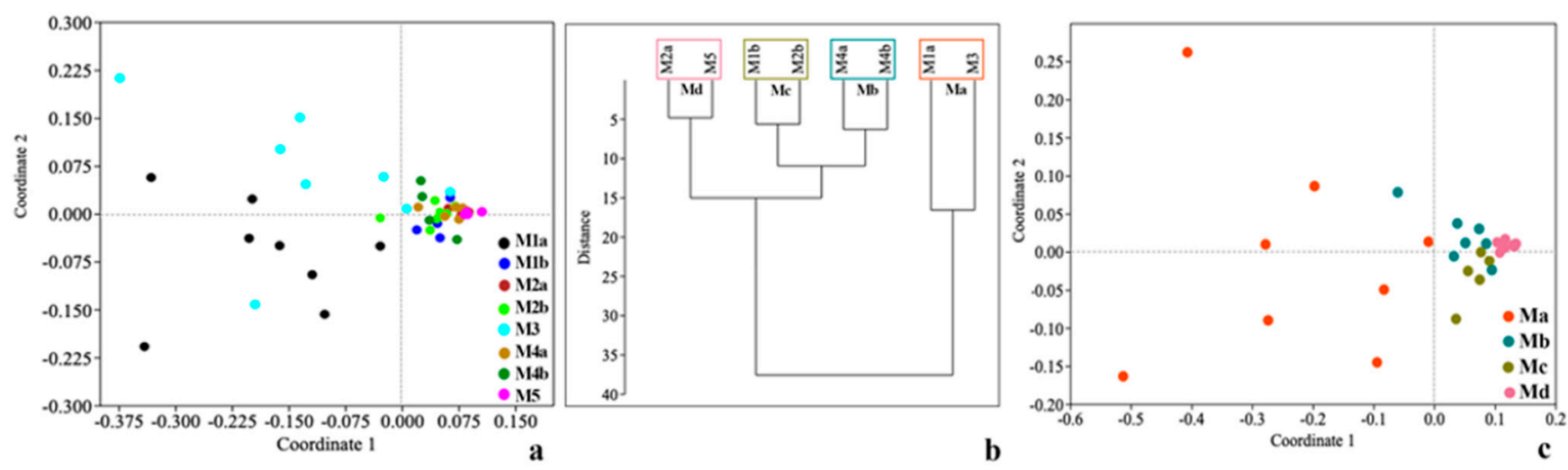

Figure 5. Vegetation patterns in microsites (MSs) of Pasargadae. (a) NMDS ordination for the eight detected MSs; (b) similarity rate in vegetation data among the different MSs occurring in the different monuments and the resulting four main groups (on the top); (c) NMDS ordination of the resulting four groups of MSs.

The Species Abundance Distribution, which visualizes the differences of microsites colonization and their suitability for plant settlement (Figure 6), clearly showed that M1a and M3 were the most colonized microsites, with a greater plant cover in M1a than in M3. On the contrary, M5 showed the poorest colonization since only 30 species with a low abundance were observed there.

Among the 142 species, four species (3\%) were observed in only one MS and 20 species $(14 \%)$ in only two MSs (M1a and M3) (Figure 7b). A number of 49 species (35\%) could colonize more than seven MSs and showed a high adaptivity to different micro-habitats (Figure $7 \mathrm{a}$ ). The $59 \%$ of species resulted as the most common and adaptable plants since they were observed in more than five MSs. Regarding the 17 species $(12 \%)$ occurring in all MSs, we could say that for them the different conditions found at the MSs did not act as limiting factors.

The differential preference of the species for each microsite, with respect to the others, is presented in Table 3. M1a, followed by M3, presented species with the highest positive deviations, and species with the lowest negative deviations. Conversely, M5, M2a, and M4a showed the opposite condition, with the lowest positive deviations and the highest negative deviations. Although the remaining microsites showed a relatively equilibrated proportion between positive and negative deviations, M1b and M4b had higher positive values, whereas $\mathrm{M} 2 \mathrm{~b}$ had higher negative ones.

By selecting the most five abundant species in each MS, Hordeum murinum, H. bulbosum, H. distichon, Melica persica, and Taeniatherum caput-medusae resulted in the most widely adapted species to the different micro-habitats, occurring in seven different microsites, followed by Lactuca serriola, L. scarriolides, and Falcaria vulgaris, which occurred in six or five different microsites. In between, some species had the highest abundancy just in some microsites such as Centaurea bruguierana, Crepis sancta subsp. nemausensis, Cyanus depressus, Scorzonera tunicata, and Plantago lanceolata in M3, which provided high accessibility to the soil. The highest value of abundancy in M1a was presented by Achillea vermicularis and Medicago montana, and in M5 by Camelina hispida and Valerianella szovitsiana.

The values indicate the deviation between the average cover of the species growing in each microsite with respect to others (Van der Maarel scale) and consider the differences among the most extreme values. The green (positive values) and red (negative values) 
colors show, respectively, the top five species with the highest and the lowest preference for each microsite with respect to others.

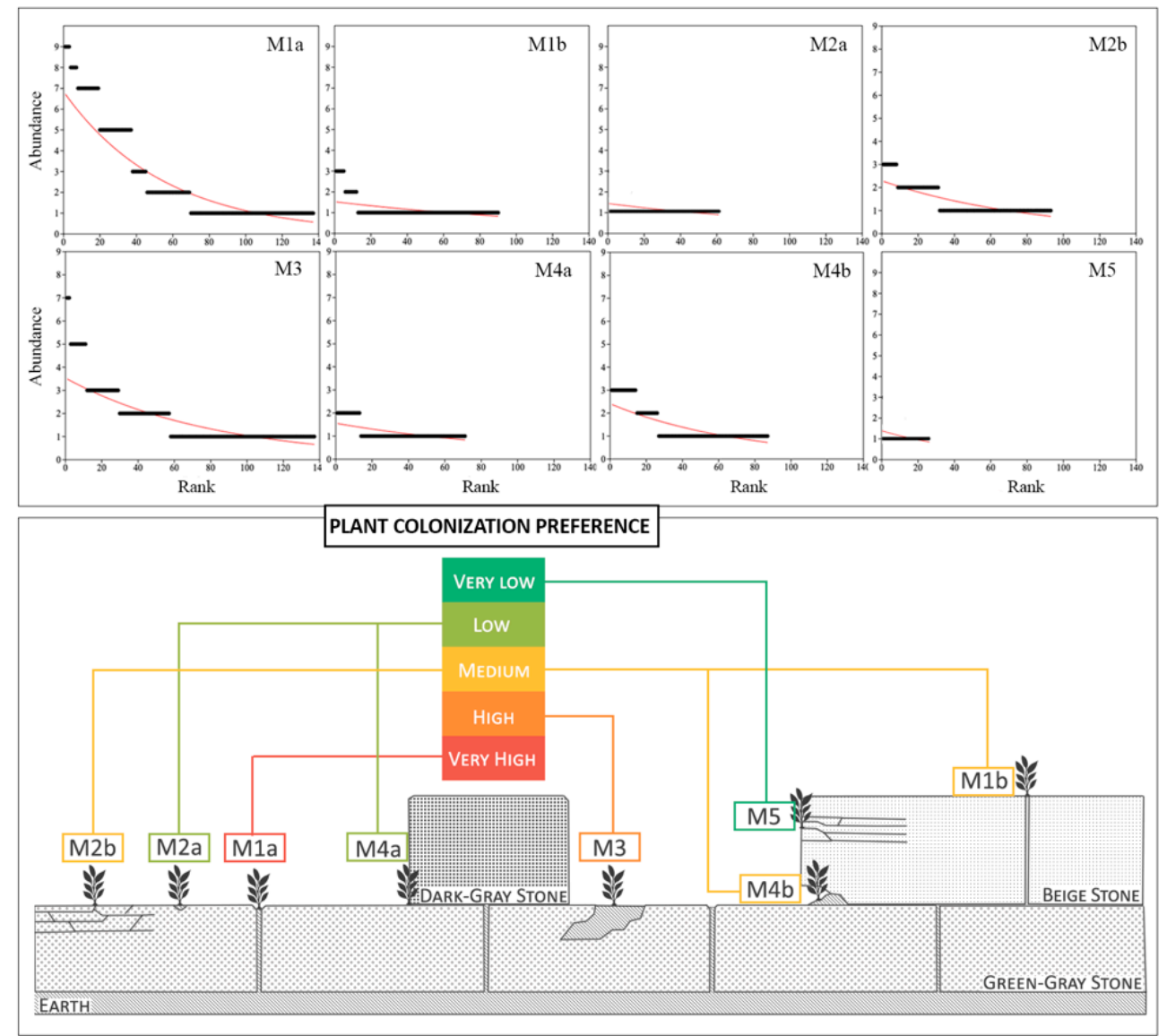

Figure 6. The SAD in different microsites is based on the Van der Maarel coverage scale. (M1a) joints and big fractures between stone blocks; (M1b) narrow joints on the same type of stone; (M2a) cavities of stone blocks; (M2b) damaged parts of stone blocks; (M3) surfaces covered by soil; (M4a) junctions between the vertical and horizontal surface, (M4b) cavities on corners and at the junction of a vertical and horizontal surface; (M5) sites between horizontal sedimentary layers of stone blocks and cracks.

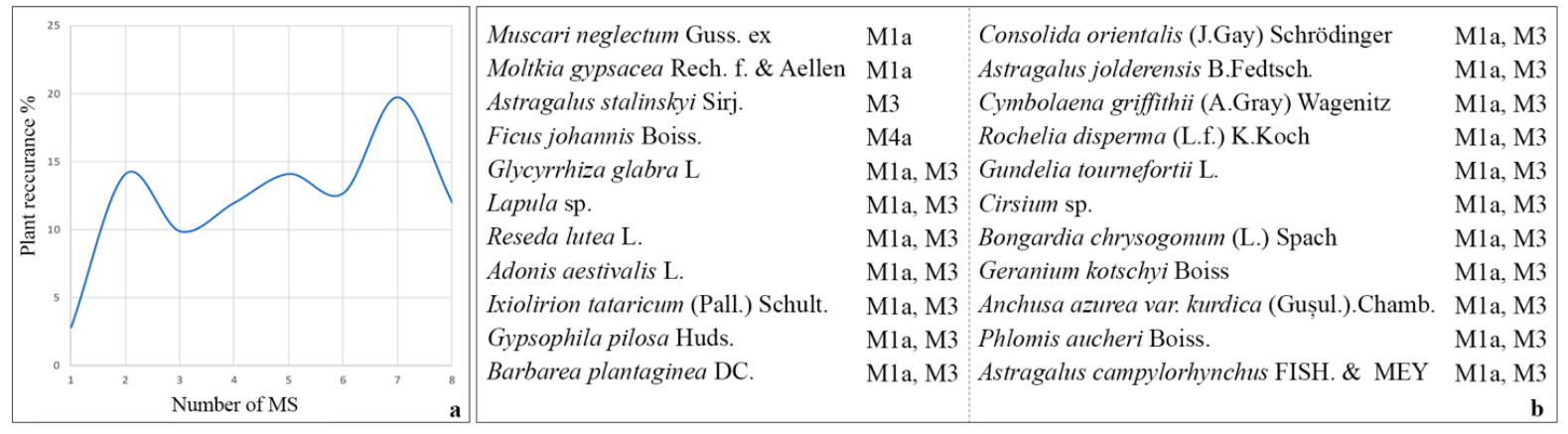

Figure 7. Plant recurrence in the microsites: (a) percentage of plant recurrence in each MS according to their differential cover; (b) plants observed only in one or two MS, listed according to their values.

The distribution of life forms related to the microsites is shown in Figure 8. The MSs M2a, M4a, and M5 were the least colonized by all the biological forms, except for M5, which mainly presented Therophytes. M1b and M4b also showed a low suitability for almost all the biological forms, apart from Chamaephytes. Conversely, M1a, M3 and, M2b appeared to exhibit an approximate affinity with all the biological forms, but with some 
differences. Chamaephytes manifested the tendency to be more linked to M3, Geophytes, and Hemicryptophytes to M1a, and Therophytes to M2b. On the other hand, Therophytes and Hemicryptophytes showed a low preference for M3; M2b seemed to be avoided by Hemicryptophytes and Chamaephytes.

Table 3. Species with a differential preference for a microsite following decreasing values of deviations.

\begin{tabular}{|c|c|c|c|c|c|c|c|}
\hline \multicolumn{2}{|l|}{ M1a } & \multicolumn{2}{|l|}{ M1b } & \multicolumn{2}{|l|}{ M2a } & \multicolumn{2}{|l|}{ M2b } \\
\hline Species & Dev & Species & Dev & Species & Dev & Species & Dev \\
\hline Hordeum bulbosum & 3.35 & Cynodon dactylon & 0.67 & Fumaria parviflora & 0.38 & Senecio glaucus & 1.13 \\
\hline Hordeum murinum & 3.14 & Hordeum distichon & 0.64 & Minuartia hirsuta & 0.09 & Poa bulbosa & 1.05 \\
\hline Cynodon dactylon & 3.07 & Taeniatherum caput-medusae & 0.60 & Androsace maxima & -0.01 & Tragopogon graminifolius & 0.90 \\
\hline Taeniatherum caput-medusae & 2.94 & Hordeum murinum & 0.51 & Erodium cicutarium & -0.03 & Plantago lanceolata & 0.68 \\
\hline Medicago persica & 2.88 & Hordeum bulbosum & 0.43 & Bongardia chrysogonum & -0.04 & Hordeum distichon & 0.68 \\
\hline Astragalus stalinskyi & -0.03 & Medicago sativa & -0.88 & Triticum aestivum & -1.09 & Aegilops tauschii & -0.59 \\
\hline Euphorbia sororia & -0.08 & Senecio glaucus & -0.89 & Tragopogon collinus & -1.12 & Cynodon dactylon & -0.63 \\
\hline Sanguisorba minor & -0.12 & Medicago persica & -0.90 & Hordeum bulbosum & -1.15 & Gundelia tournefortii & -0.66 \\
\hline Solanum nigrum & -0.14 & Medicago monantha & -0.91 & Podospermum grossheimii & -1.28 & Triticum aestivum & -0.70 \\
\hline Androsace maxima & -0.16 & Lactuca serriola & -0.98 & Cynodon dactylon & -1.46 & Glycyrrhiza glabra & -0.73 \\
\hline M3 & & M4a & & M4b & & M5 & \\
\hline Species & $\overline{\text { Dev }}$ & Species & Dev & Species & Dev & Species & Dev \\
\hline Scorzonera cinerea & 2.26 & Aegilops umbellulata & 0.30 & Lolium perenne & 0.82 & Scrophularia striata & 0.003 \\
\hline Tragopogon graminifolius & 2.06 & Linaria sp. & 0.23 & Alopecurus arundinaceus & 0.78 & Convolvulus arvensis & -0.09 \\
\hline Centaurea bruguierana & 2.03 & Androsace maxima & 0.22 & Bromus tomentellus & 0.78 & Avena fatua & -0.14 \\
\hline Tragopogon collinus & 2.01 & Agrostis gigantea & 0.22 & Bromus tectorum & 0.73 & Camelina hispida & -0.17 \\
\hline Glycyrrhiza glabra & 2.00 & Ficus johannis & 0.17 & Lactuca scarioloides & 0.69 & Triticum aestivum & -0.17 \\
\hline Sanguisorba minor & -0.12 & Plantago lanceolata & -0.97 & Tragopogon collinus & -0.81 & Senecio glaucus & -1.57 \\
\hline Heteranthelium piliferum & -0.12 & Scorzonera tunicata & -1.02 & Cynodon dactylon & -0.93 & Hordeum distichon & -1.69 \\
\hline Avena fatua & -0.21 & Tragopogon collinus & -1.04 & Plantago lanceolata & -0.97 & Taeniatherum caputmedusae & -1.72 \\
\hline Triticum aestivum & -0.24 & Tragopogon graminifolius & -1.24 & Tragopogon graminifolius & -1.01 & Hordeum murinum & -1.81 \\
\hline Cynodon dactylon & -0.29 & Scorzonera cinerea & -1.29 & Scorzonera cinerea & -1.07 & Hordeum bulbosum & -1.89 \\
\hline
\end{tabular}

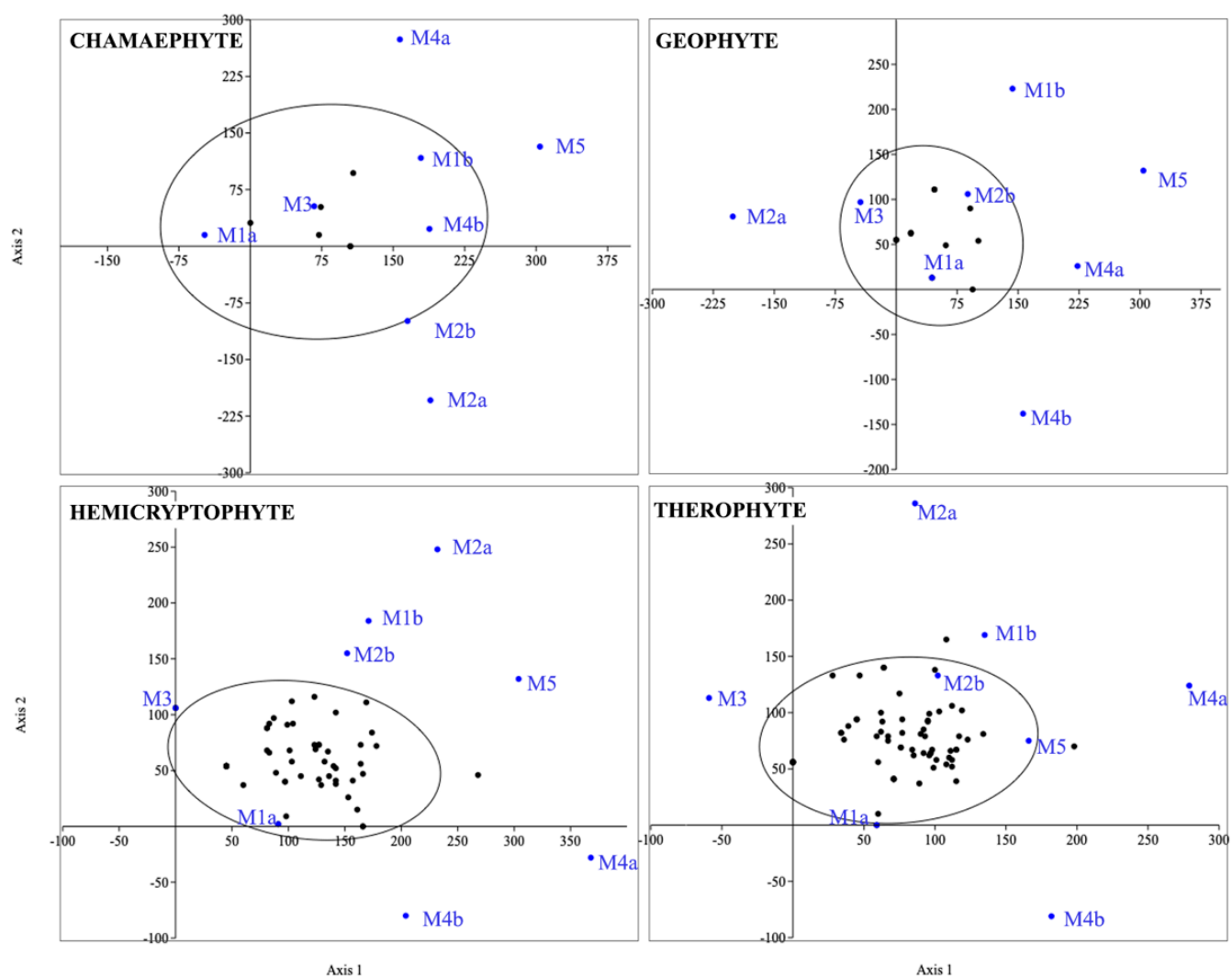

Figure 8. DCA analysis of the distribution of species in different MSs based on their life forms. (Chamaephytes: woody plants with buds at no more than $25 \mathrm{~cm}$ above the soil surface; Geophytes: perennial herbs with underground storage organs; Hemicryptophytes: perennial herbs; Therophytes: annual herbs). 


\section{Discussion}

\subsection{Plant Colonization Similarity among the Monuments}

There were several factors to consider when assessing the floristic affinity among monuments and their biodiversity values, including the size of the analyzed area, the occurring stone, their previous weathering, and the human interventions of regular maintenance $[3,17,68]$. In fact, as the most relevant and visited monument on the site, the Cyrus Tomb is under periodic maintenance, so the chance of seed settlement, germination, and growth were noticeably lower than in the other parts of the site. Conversely, Watercourses had the highest rate of species richness, as they were built with porose Green-Gray stone, and due to the severe weathering of the stone, their location and dimensions limit the possibility of monitoring and conservation activities.

The lack of maintenance facilitates the natural weathering of construction materials. Weathering causes an increase in material porosity, grain disintegration, formation of fissures and cracks, which also encourage microbial growth and allow the rooting of higher plants on building surfaces $[4,43,68]$. Prolonged human negligence increases the bioreceptivity of building materials to plant colonization, while the conservation state of building materials and their maintenance influences the rate of colonization on structures $[4,22,39,41,42,45]$. However, the balance between the need to preserve natural and cultural values is an aspect, which should also be considered in management plans $[13,20,21]$, and this topic will be considered in a further contribution.

The PCA analysis showed humidity to be the first discriminating environmental factor that affected the vegetation affinity between monuments. In fact, in the main ordination axis, monuments followed a sequence from the driest (Cyrus Tomb) to the moistest conditions (Watercourses). This factor confirmed the recurrently observed relevance of water as a primary limiting factor for the biodeterioration of stone monuments $[25,32,33]$. Secondly, as often observed $[5,6,8]$, human disturbance results in a relevant discriminating factor. In this regard, the opposite conditions of Caravanserai with respect to Watercourses could be explained by the fact that the first one is located very close to the tourist paths and gates; whereas, the latter are in the place with the most natural and undisturbed conditions. This interpretation was also supported by the location and human disturbance of the other monuments.

When considering the species with the highest values for each monument, species of arid habitats were found abundantly on the Cyrus Tomb, including species adapted to trampling and human disturbance, such as Solanum nigrum and Malva neglecta. Similarly, plants of human-disturbed habitats, such as Falcaria vulgaris, Sisymbrium septulatum, Cynodon dactylon, and Hordeum distichon, were also highly recurrent in Caravanserai. On the other hand, in Watercourses, we found several species that prefer moist habitats, such as Alhagi maurorum, Alhagi pseudalhagi, and Glycyrrhiza glabra.

\subsection{Stone Preference for Plant Colonization}

The degree of biological colonization of a stone surface highly depends on the intrinsic properties of the material [36]. Thus, two different types of stone may undergo different degrees of colonization under the same environmental conditions [31,39]. The intrinsic properties of the stone (hardness, porosity, and the rate of water absorption) are limiting factors that determine the ability of a material to be colonized by a living organism, as well as the rate and type of plant colonization [6,24,38-40,69]. Additionally, stone typology directly affects the rate of weathering and determines the microsite of the plant settlement [70]. In fact, the stone might have different mineral compositions, textures, and structures, resulting in a great variety of physical and chemical characteristics [39].

Our data confirmed that the stone typology had a significant effect on the biodiversity and species richness. Both Beige and Green-Gray stones were colonized by a large variety of species; however, the abundance and frequency of species on both stones made the differences more apparent. Beige stones were observed in a better condition than the others due to their physical stability, lower porosity, and compact structure. Green-Gray stones, 
which have a similar texture, are composed of different grains such as calcite, dolomite, quartz, opal, and clay [59]. In addition, clay is the most important factor in the deterioration of the petrology of this kind of stone because of the clay swelling phenomenon [58]. If the stone remains wet long enough, the growth of the biofilm, production of organic matter, and humification processes may produce protosoils, which may favor the settlement of mosses and higher plants [31,41].

\subsection{Vegetation Patterns in Microsites}

Results confirmed that the MS in horizontal surfaces provided highly suitable conditions for plants, due to the highest water content and substrate accessibility. It also had the highest chance of seeds landing, since it was a good perch for birds that excrete seeds, or a suitable site for ant nests where seeds are stored $[9,45,69]$. In Pasargadae, the colonization in joints and big fractures of stone blocks (M1a) and surfaces covered by soil (M3) clearly represented the most suitable conditions, not only in regards to the frequency of species, as it was already detected [24], but also in regards to the coverage of ruderal plants. In M1a, all biological forms were found, and the higher colonization in M1a than M3 could be explained by the soil depth. Plants that grew at the junction of two stone blocks could reach the subsoil, while in M3, besides the high accessibility of soil, the roots were limited by the bedrock of stone blocks. Indeed, here a high number of species with a low abundance were recurring due to their favorable conditions for the settlement of any plant species. In fact, these two MSs provided high accessibility to the soil, water, and nutrients, resulting in suitable conditions for plant development and root expansion, reducing the environmental stress of ruderal plants [24]. Therefore, a certain number of species were only correlated to these two MSs. The absence of these plants in other MSs indicated the reluctance and incompatibility of these plants with extreme habitats with low soil/moisture accessibility and low possibility of root development.

Damaged parts of stone blocks (M2b), cavities at the junction of two stone blocks (M4b), and narrow joints of the same type of stone (M1b) provided a relatively suitable habitat for plant development as they could trap soil and dust [9], even if the plant abundance did not exceed the $25 \%$ of coverage. On the contrary, between horizontal sedimentary layers of stone blocks and cracks (M5), cavities of homogenous stone blocks (M2a), and narrow junctions between the vertical and horizontal surfaces (M4a), were the most extreme habitats due to the lack of soil/moisture accessibility, and high environmental stress. The low rate and abundance of plant species that could colonize these MSs showed that although some species could settle in these MSs, they were not able to be largely distributed.

The differential preference of species such as Cynodon dactylon, Hordeum distichon, $H$. bulbosum, H. murinum, and Taeniatherum caput-medusae, belonging to the Poaceae family, in fractures and joints of stone blocks (M1a, M1b and M4b) could be explained by their morphology characterized by thin and long structures, which make them more suitable to grow, and expand their roots in this type of spaces.

Plants with bulbous (e.g., Poa bulbosa) and rhizomatous root systems or tap roots (e.g., Scorzonera cinerea, Tragopogon graminifolius, T. collinus) showed a preference for the colonization of surfaces covered by soil or debris (M3 and M2b), probably because there was sufficient space for root expansion and collecting water since they could not reach the subsoil for water absorption. Species that preferred colonizing cavities and cracks of stone blocks (M2a, M4a, M5) were mostly small therophytes (e.g., Androsace maxima, Minuarta hirsuta, Aegilops umbellata, Camelina hispida), which were the most suitable species to grow in such extreme conditions.

\section{Conclusions}

The colonization of stone monuments by ruderal plants and vegetation is a complex process influenced by the characteristics and extension of the area, by the intrinsic properties of the stone materials (mineralogical composition, porosity, etc.), and by the possibility 
of constituting a suitable site for seed settlement and plant establishment. Extrinsic factors, such as climatic conditions, the lack of maintenance, and an inappropriate vegetation management plan, also have a relevant role. Better knowledge on the substrate preference of plant colonization on monuments can provide useful information for appropriate management of the site and for an evaluation of further biodeterioration phenomena. In fact, evaluating the substrate preference of plants could allow the identification of high-risk areas for plant colonization, which could then be considered in the management plan for the periodic monitoring or conservation activities for decreasing the rate of biodeterioration phenomena. The collected data in the Pasargadae WHS emphasized the significance of site characteristics and maintenance activities, such as stone typology, and MS, in influencing the species composition, diversity, and richness.

Supplementary Materials: The following are available online at https:/ / www.mdpi.com/article/ 10.3390/su13169381/s1, Table S1: substrate factors and management activities in Pasargadae, as influencing factors for the plant colonization, Table S2: data matrix of floristic data and their coverage (based on the Van-der Maarel scale) in: (a) the nine analyzed monuments; (b) the two stones; (c) the eight described microsites.

Author Contributions: Conceptualization, G.C. and Z.H.; methodology, G.C., Z.H. and M.C.; validation, G.C.; formal analysis, M.C., G.Z. and Z.H.; investigation and data analysis, Z.H.; writingoriginal draft, Z.H.; writing-review and editing, G.C. and G.Z.; supervision, G.C.; project administration, G.C. All authors have read and agreed to the published version of the manuscript.

Funding: This research was conducted as part of a Ph.D. study and funded as a Ph.D. scholarship by the University Roma Tre, Science Department. The Grant of Excellence Departments, MIUR, Italy (Art. 1, commi 314-337 legge 232/2016), is gratefully acknowledged.

Acknowledgments: We thank our colleagues, Fernando Lucchese, Flavia Bartoli, and Emanuela Cicinelli, at the Department of Science of the University Roma Tre, who greatly helped with the floristic assessment of the study area. We also thank Hossein Akhani, Nafiseh Samadi, and Alexander Rudov at the Biology Department of the University of Tehran, for their kind assistance in the plant identification. We would also like to show our gratitude to Hamid Fadaei, the site manager, and other colleagues at the Pasargadae World Heritage Site for their support during the field surveys, for making accessible the archive and providing the possibility of laboratory studies. We would like to mention that any eventual errors are ours and should not tarnish the reputations of these esteemed collaborators.

Conflicts of Interest: The authors declare no conflict of interest.

\section{References}

1. Caneva, G. Tree roots and hypogean conservation. Braun Blanquetia 1989, 3, 329-336.

2. Krigas, N.; Lagiou, E.; Hanlidou, E.; Kokkini, S. The vascular flora of the byzantine walls of Thessaloniki (N Greece). Willdenowia 1999, 29, 77-94. [CrossRef]

3. Celesti-Grapow, L.; Blasi, C. The role of alien and native weeds in the deterioration of archaeological remains in Italy. Weed Technol. 2004, 18, 1508-1513. [CrossRef]

4. Jim, C.Y.; Chen, W.Y. Bioreceptivity of buildings for spontaneous arboreal flora in compact city environment. Urban. For. Urban. Green. 2011, 10, 19-28. [CrossRef]

5. Kumbaric, A.; Ceschin, S.; Zuccarello, V.; Caneva, G. Main ecological parameters affecting the colonization of higher plants in the biodeterioration of stone embankments of Lungotevere (Rome). Int. Biodeterior. Biodegrad. 2012, 72, 31-41. [CrossRef]

6. Ceschin, S.; Bartoli, F.; Salerno, G.; Zuccarello, V.; Caneva, G. Natural habitats of typical plants growing on ruins of Roman archaeological sites (Rome, Italy). Plant. Biosyst. Int. J. Deal. All Asp. Plant. Biol. 2016, 150, 866-875. [CrossRef]

7. Almeida, M.T.; Mouga, T.; Barracosa, P. The weathering ability of higher plants. The case of Ailanthus Altissima (Miller) swingle. Int. Biodeterior. Biodegrad. 1994, 33, 333-343. [CrossRef]

8. Láníková, D.; Lososová, Z. Rocks and walls: Natural versus secondary habitats. Folia Geobot 2009, 44, 263. [CrossRef]

9. Lisci, M.; Pacini, E. Plants growing on the walls of Italian towns 1. Sites and distribution. Phyton 1992, 32, 13. [CrossRef]

10. Caneva, G.; Pacini, A.; Celesti Grapow, L.; Ceschin, S. The Colosseum's use and state of abandonment as analysed through its Flora. Int. Biodeterior. Biodegrad. 2003, 51, 211-219. [CrossRef]

11. Trotta, G.; Savo, V.; Cicinelli, E.; Carboni, M.; Caneva, G. Colonization and damages of Ailanthus altissima (Mill.) Swingle on archaeological structures: Evidence from the Aurelian Walls in Rome (Italy). Int. Biodeterior. Biodegrad. 2020, $153,105054$. [CrossRef] 
12. Motti, R.; Stinca, A. Analysis of the biodeteriogenic vascular flora at the Royal Palace of Portici in Southern Italy. Int. Biodeterior. Biodegrad. 2011, 65, 1256-1265. [CrossRef]

13. Caneva, G.; Benelli, F.; Bartoli, F.; Cicinelli, E. Safeguarding natural and cultural heritage on Etruscan tombs (La Banditaccia, Cerveteri, Italy). Rend. Lincei. Sci. Fis. E Nat. 2018, 29, 891-907. [CrossRef]

14. Dahmani, J.; Benharbit, M.; Fassar, M.; Hajila, R.; Zidane, L.; Magri, N.; Belahbib, N. Vascular plants census linked to the biodeterioration process of the portuguese city of Mazagan in El Jadida, Morocco. J. King Saud Univ. Sci. 2020, 32, 682-689. [CrossRef]

15. Dabghi, A.; Magri, N.; Achoual, K.; Belahbib, N.; Benharbit, M.; Dahmani, J. Floristic diversity and its biodeteriogenic effect on the archaeological site of Volubilis (Morocco). Plant. Cell Biotechnol. Mol. Biol. 2021, 22, 53-70.

16. Celesti Grapow, L.; Caneva, G.; Pacini, A. La flora del Colosseo (Roma). Webbia 2001, 56, 321-342. [CrossRef]

17. Caneva, G.; Cutini, M.; Pacini, A.; Vinci, M. Analysis of the Colosseum's floristic changes during the last four centuries. Plant. Biosyst. Int. J. Deal. All Asp. Plant. Biol. 2002, 136, 291-311. [CrossRef]

18. Ceschin, S.; Cutini, M.; Caneva, G. Contributo alla conoscenza della vegetazione delle aree archeologiche romane (Roma). Fitosociologia 2006, 43, 97-139. [CrossRef]

19. Altay, V.; Özyiğit, İ.; Yarci, C. Urban ecological characteristics and vascular wall flora on the Anatolian side of Istanbul, Turkey. Maejo Int. J. Sci. Technol. 2010, 4, 483-495.

20. Minissale, P.; Trigilia, A.; Brogna, F.; Sciandrello, S. Plants and vegetation in the archaeological park of Neapolis of Syracuse (Sicily, Italy): A management effort and also an opportunity for better enjoyment of the site. Conserv. Manag. Archaeol. Sites 2015, 17, 340-369. [CrossRef]

21. Papafotiou, M.; Kanellou, E.; Economou, G. Integrated design and management of vegetation at archaeological sites to protect monuments and enhance the historical landscape. Acta Hortic. 2017, 1-10. [CrossRef]

22. Motti, R.; Bonanomi, G. Vascular plant colonisation of four castles in southern Italy: Effects of substrate bioreceptivity, local environment factors and current management. Int. Biodeterior. Biodegrad. 2018, 133, 26-33. [CrossRef]

23. De Marco, G.; Caneva, G.; Dinelli, A. Geobotanical foundations for a protection project in the Moenjodaro archaeologocal area. Prospez. Archeol. Quad. 11990, 15, 115-120.

24. Hosseini, Z.; Caneva, G. Evaluating hazard conditions of plant colonization in pasargadae world heritage site (Iran) as a tool of biodeterioration assessment. Int. Biodeterior. Biodegrad. 2021, 160, 105216. [CrossRef]

25. Caneva, G.; Salvadori, O.; Ricci, S.; Ceschin, S. Ecological analysis and biodeterioration processes over time at the hieroglyphic stairway in the Copàn (Honduras) archaeological site. Plant. Biosyst. Int. J. Deal. All Asp. Plant. Biol. 2005, 139, 295-310. [CrossRef]

26. Mishra, A.K.; Jain, K.K.; Garg, K.L. Role of higher plants in the deterioration of historic buildings. Sci. Total Environ. 1995, 167, 375-392. [CrossRef]

27. Kumar, R.; Kumar, A.V. Biodeterioration of Stone in Tropical Environments: An Overview; Getty: Los Angeles, CA, USA, 1999.

28. Bartoli, F.; Casanova Municchia, A.; Futagami, Y.; Kashiwadani, H.; Moon, K.H.; Caneva, G. Biological colonization patterns on the ruins of Angkor Temples (Cambodia) in the biodeterioration vs bioprotection debate. Int. Biodeterior. Biodegrad. 2014, 96, 157-165. [CrossRef]

29. Aung, M.Z.N.; Shibata, S. Vegetation conditions in sacred compounds at Myanmar's Bagan cultural heritage site. Heritage 2019, 2, 170. [CrossRef]

30. Capotorti, G.; Del Vico, E.; Lattanzi, E.; Tilia, A.; Celesti-Grapow, L. Exploring biodiversity in a metropolitan area in the Mediterranean region: The urban and suburban flora of Rome (Italy). Plant. Biosyst. Int. J. Deal. All Asp. Plant. Biol. 2013, 147, 174-185. [CrossRef]

31. Caneva, G.; Nugari, M.P.; Nugari, M.P.; Salvadori, O. Plant. Biology for Cultural Heritage: Biodeterioration and Conservation; Getty Publications: Los Angeles, CA, USA, 2008; ISBN 9780892369393.

32. Caneva, G.; Bartoli, F.; Savo, V.; Futagami, Y.; Strona, G. Combining statistical tools and ecological assessments in the study of biodeterioration patterns of stone temples in Angkor (Cambodia). Sci. Rep. 2016, 6, 1-8. [CrossRef]

33. Liu, X.; Meng, H.; Wang, Y.; Katayama, Y.; Gu, J.-D. Water is a critical factor in evaluating and assessing microbial colonization and destruction of Angkor sandstone monuments. Int. Biodeterior. Biodegrad. 2018, 133, 9-16. [CrossRef]

34. Danin, A.; Caneva, G. Deterioration of limestone walls in Jerusalem and marble monuments in Rome caused by cyanobacteria and cyanophilous lichens. Int. Biodeterior. 1990, 26, 397-417. [CrossRef]

35. Lombardozzi, V.; Castrignanò, T.; D'Antonio, M.; Casanova Municchia, A.; Caneva, G. An interactive database for an ecological analysis of stone biopitting. Int. Biodeterior. Biodegrad. 2012, 73, 8-15. [CrossRef]

36. Guillitte, O. Bioreceptivity: A new concept for building ecology studies. Sci. Total Environ. 1995, 167, 215-220. [CrossRef]

37. Miller, A.Z.; Dionísio, A.; Laiz, L.; Macedo, M.F.; Saiz-Jimenez, C. The influence of inherent properties of building limestones on their bioreceptivity to phototrophic microorganisms. Ann. Microbiol. 2009, 59, 705-713. [CrossRef]

38. Jain, A.; Bhadauria, S.; Kumar, V.; Chauhan, R.S. Biodeterioration of sandstone under the influence of different humidity levels in laboratory conditions. Build. Environ. 2009, 44, 1276-1284. [CrossRef]

39. Miller, A.Z.; Sanmartín, P.; Pereira-Pardo, L.; Dionísio, A.; Saiz-Jimenez, C.; Macedo, M.F.; Prieto, B. Bioreceptivity of building stones: A review. Sci. Total Environ. 2012, 426, 1-12. [CrossRef] 
40. D'Orazio, M.; Cursio, G.; Graziani, L.; Aquilanti, L.; Osimani, A.; Clementi, F.; Yéprémian, C.; Lariccia, V.; Amoroso, S. Effects of water absorption and surface roughness on the bioreceptivity of ETICS compared to clay bricks. Build. Environ. 2014, 77, 20-28. [CrossRef]

41. Ortega-Calvo, J.J.; Ariño, X.; Hernandez-Marine, M.; Saiz-Jimenez, C. Factors affecting the weathering and colonization of monuments by phototrophic microorganisms. Sci. Total Environ. 1995, 167, 329-341. [CrossRef]

42. Ramírez, M.; Hernández-Mariné, M.; Novelo, E.; Roldán, M. Cyanobacteria-containing biofilms from a Mayan monument in Palenque, Mexico. Biofouling 2010, 26, 399-409. [CrossRef]

43. Urzì, C.; De Leo, F.; De Hoog, S.; Sterflinger, K. Recent advances in the molecular biology and ecophysiology of meristematic stone-inhabiting fungi. In Of Microbes and Art: The Role of Microbial Communities in the Degradation and Protection of Cultural Heritage; Ciferri, O., Tiano, P., Mastromei, G., Eds.; Springer: Boston, MA, USA, 2000; pp. 3-19. ISBN 9781461542391.

44. Korkanç, M.; Savran, A. Impact of the surface roughness of stones used in historical buildings on biodeterioration. Constr. Build. Mater. 2015, 80, 279-294. [CrossRef]

45. Lisci, M.; Monte, M.; Pacini, E. Lichens and higher plants on stone: A review. Int. Biodeterior. Biodegrad. 2003, 51, 1-17. [CrossRef]

46. Chambrade, M.-L.; Gondet, S.; Laisney, D.; Mehrabani, M.; Mohammadkhani, K.; Zareh-Kordshouli, F. The canal system of Ju-i Dokhtar: New insight into water management in the eastern part of the Pasargadae Plain (Fars, Iran). Water Hist. 2020, 12, 449-476. [CrossRef]

47. Heshmati, G.A. Vegetation characteristics of four ecological zones of Iran. Int. J. Plant. Prod. 2012, 1, 215-224. [CrossRef]

48. Henkelman, W.F. The Achaemenid heartland: An archaeological-historical perspective. A Companion Archaeol. Anc. Near East. 2012, 1, 931-962.

49. Stronach, D. Excavations at pasargadae: First preliminary report. Iran 1963, 1, 19-42. [CrossRef]

50. Boucharlat, R. Pasargadae. Iran 2002, 40, 279-282. [CrossRef]

51. Stronach, D. Excavations at Pasargadae: Third preliminary report. Iran 1965, 3, 9-40. [CrossRef]

52. Talebian, M.H. The current state of heritage management at Pasargadae. Problems and Prospects. In World Heritage in Iran; Taylor Francis Group: Abingdon, UK, 2014.

53. Rigot, J.-B.; Gondet, S.; Chambrade, M.-L.; Djamali, M.; Mohammadkhani, K.; Thamó-Bozsó, E. Pulvar River changes in the Pasargadae Plain (Fars, Iran) during the Holocene and the consequences for water management in the first millennium BCE. Quat. Int. 2021. [CrossRef]

54. Sami, A. Pasargadae: The Oldest Imperial Capital of Iran. Learned Society of Pars; Musavi Printing Office: Shiraz, Iran, 1956.

55. Djamali, M.; Akhani, H.; Khoshravesh, R.; Andrieu-Ponel, V.; Ponel, P.; Brewer, S. Application of the global bioclimatic classification to Iran: Implications for understanding the modern vegetation and biogeography. Ecol. Mediterr. 2011, 37, 91-114. [CrossRef]

56. Emami, M.; Eslami, M.; Fadaei, H.; Karami, H.R.; Ahmadi, K. Mineralogical-geochemical characterization and provenance of the stones used at the Pasargadae complex in Iran: A new perspective. Archaeometry 2018, 60, 1184-1201. [CrossRef]

57. Shekofteh, A.; Ahmadi, H.; Yazdi, M. Relationship between the durability and fabric of Pasargadae carbonate stones (Archaelogical Site from Achaemenid Period, South of Iran). Sci. Art A Future Stone 2016, 133-138.

58. Shekofteh, A.; Molina, E.; Arizzi, A.; Cultrone, G.; Ahmadi, H.; Yazdi, M. Characterization and damage assessment of stones used in the Pasargadae World Heritage Site, Achaemenian period. Int. J. Archit. Herit. 2019, 13, 521-536. [CrossRef]

59. Shekofteh, A.; Ahmadi, H.; Yazdi, M. Chemical composition and decay patterns of stones used in Pasargadae World Heritage Site. J. Maremat Me'mari-E Iran Art Univ. Isfahan 2018, 7, 27-44.

60. Van der Maarel, E. Transformation of cover-abundance values in phytosociology and its effects on community similarity. Vegetatio 1979, 39, 97-114. [CrossRef]

61. Raunkiaer, C. The Life Forms and Statistical Plant Geography; Oxford Clarendon Press: Oxford, UK, 1934.

62. Hartigan, J.A. Consistency of single linkage for high-density clusters. J. Am. Stat. Assoc. 1981, 76, 388-394. [CrossRef]

63. Magurran, A.E. Ecological Diversity and Its Measurement; Princeton University Press: Princeton, NJ, USA, 1988 ; ISBN 0709935404.

64. Dornelas, M. Disturbance and change in biodiversity. Phil. Trans. R. Soc. B 2010, 365, 3719-3727. [CrossRef] [PubMed]

65. Hill, M.O.; Gauch, H.G. Detrended correspondence analysis: An improved ordination technique. Vegetatio 1980, 42, 47-58. [CrossRef]

66. Jackson, D.A.; Somers, K.M. Putting things in order: The ups and downs of detrended correspondence analysis. Am. Nat. 1991, 137, 704-712. [CrossRef]

67. Fisher, R.A. Statistical Methods for Research Workers; Oliver and Boyd: Edinburgh, Scotland, 1925; p. 6.

68. Cicinelli, E.; Benelli, F.; Bartoli, F.; Traversetti, L.; Caneva, G. Trends of plant communities growing on the Etruscan tombs (Cerveteri, Italy) related to different management practices. Plant. Biosyst. Int. J. Deal. All Asp. Plant. Biol. 2020, 154, 158-164. [CrossRef]

69. Segal, S. Ecological Notes on Wall Vegetation; Springer: Amsterdam, The Netherlands, 1969; ISBN 9789401758024.

70. Pocock, C. An investigation into plant species composition on the Roman wall in Silchester, Hampshire, UK. Geoverse 2008. Available online: http://geoverse.brookes.ac.uk/article_resources/pocockC/pocockC.htm (accessed on 15 August 2021). 